\title{
Karyotype of Homolobus infumator (Lyle, 1914) (Hymenoptera: Braconidae)
}

\author{
Кариотип Homolobus infumator (Lyle, 1914) \\ (Hymenoptera: Braconidae)
}

\author{
V.E. Gokhman, A.P. Mikhailenko \\ В.Е. Гохман, А.П. Михайленко
}

Botanical Garden, Moscow State University, Moscow 119234, Russia. E-mail: vegokhman@hotmail.com

Ботанический сад, Московский государственный университет, Москва 119234, Рocсия. E-mail: vegokhman@hotmail.com

KEY WORDS: Hymenoptera, Braconidae, Homolobinae, Homolobus, chromosomes, karyotype.

КЛЮЧЕВЫЕ СЛОВА: Hymenoptera, Braconidae, Homolobinae, Homolobus, хромосомы, кариотип.

ABSTRACT. Karyotype of a parasitic wasp of the subfamily Homolobinae, Homolobus infumator (Lyle, 1914), has been studied for the first time. The species has $2 \mathrm{n}=12$. All chromosomes of the karyotype are biarmed and slowly decrease in size. Possible origin of the karyotype of $H$. infumator is discussed in the light of phylogenetic relationships of the Homolobinae.

РЕЗЮМЕ. Впервые изучены хромосомы наездника Homolobus infumator (Lyle, 1914) из подсемейства Homolobinae. У этого вида обнаружено $2 \mathrm{n}=12$. Все хромосомы в кариотипе двуплечие, постепенно убывают по размерам. Возможное происхождение кариотипа H. infumator обсуждается в свете филогенетических отношений Homolobinae.

The family Braconidae is a large group of parasitic wasps of the superfamily Ichneumonoidea. It contains more than 17 thousand described species belonging to 47 subfamilies [Sharanowski et al., 2011]. Although karyotypes of this group were an object of a special review by the first author of the present paper [Gokhman, 2004], chromosome sets of the family Braconidae remain insufficiently studied. Specifically, chromosomes of about 60 species of Braconidae belonging to 13 subfamilies were examined up to now [Gokhman, 2009]. We have managed for the first time to explore karyotype of a member of the subfamily Homolobinae, namely, Homolobus infumator (Lyle, 1914). The results of this study are given below.

\section{Materials and methods}

An adult female collected in the MSU Botanical Garden in October 2011 was used in this study. Chromosome preparation was obtained from the ovaries of the studied specimen according to the technique described by Gokhman [2009]. Mitotic cell divisions were studied and photographed using optic microscope Zeiss
Axioskop 40 FL fitted with digital camera AxioCam MRc. Chromosomes of five diploid metaphase plates were measured on digital micrographs using Zeiss AxioVision; all chromosomes were then arranged according to the classification provided by Levan et al. [1964]. The specimen was identified by the first author; the identification was confirmed by S.A. Belokobylskij (Zoological Institute of the Russian Academy of Sciences, St. Petersburg, Russia). The studied specimen is deposited in the collection of the Zoological Museum, Moscow State University, Moscow, Russia.

\section{Results and discussion}

Mitotic metaphase plates of $H$. infumator show $2 \mathrm{n}=$ 12 (Fig. 1). All chromosomes are obviously biarmed, i.e. either metacentric or submetacentric (first, fourth, sixth and second, third and fifth pair respectively; Table 1). The chromosomes more or less gradually decrease in size; however, the first pair is obviously the largest, and the fifth and sixth pairs are visibly smaller than the remaining ones (Fig. 1). Every chromosome pair is therefore easily recognizable by its size and/or centromere index.

Table 1. Parameters of chromosomes of H. infumator (mean $\pm \mathrm{SD}$ )

Таблица 1. Параметры хромосом H. infumator (среднее значение \pm среднеквадратичное отклонение)

\begin{tabular}{|c|c|c|}
\hline $\begin{array}{c}\text { Chromosome } \\
\text { no. }\end{array}$ & $\begin{array}{c}\text { Relative } \\
\text { length }\end{array}$ & $\begin{array}{c}\text { Centromere } \\
\text { index }\end{array}$ \\
\hline 1 & $20.63 \pm 1.08$ & $45.22 \pm 1.64$ \\
\hline 2 & $18.00 \pm 0.45$ & $34.29 \pm 2.43$ \\
\hline 3 & $16.90 \pm 0.59$ & $32.81 \pm 3.36$ \\
\hline 4 & $16.79 \pm 0.40$ & $39.31 \pm 2.51$ \\
\hline 5 & $14.59 \pm 0.51$ & $34.85 \pm 2.11$ \\
\hline 6 & $13.09 \pm 0.85$ & $43.97 \pm 3.65$ \\
\hline
\end{tabular}



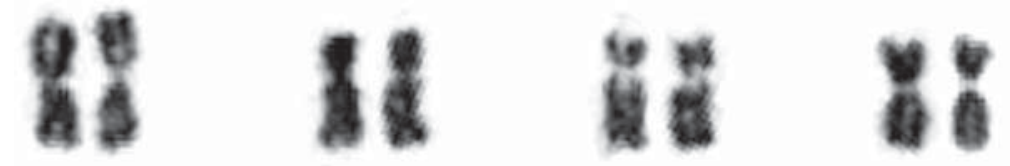

Fig. 1. Karyogram of Homolobus infumator. Scale bar $=10 \mu \mathrm{m}$.

Рис. 1. Кариограмма Homolobus infumator. Масштаб - $10 \mu \mathrm{m}$.

At present, Homolobinae are considered a part of the so-called macrocentroid subcomplex that, in turn, belongs to the helconoid complex of non-cyclostome Braconidae [Sharanowski et al., 2011]. Among six known subfamilies of the macrocentroid subcomplex, chromosomes of only Charmontinae and Macrocentrinae have been previously examined [Gokhman, 2009]. Karyotypically studied species of the two latter subfamilies strongly differ in their chromosome numbers, with $n=14$ in Macrocentrinae and $n=5-6$ in Charmontinae. In the latter group, both studied chromosome sets belong to different individuals (presumably sibling species) of Charmon cruentatus Haliday, 1833. The karyotype structure of Ch. cruentatus with $2 \mathrm{n}=12$ looks similar to that of $H$. infumator with the same chromosome number, and this similarity can testify in favour of the close phylogenetic relationship between Homolobinae and Charmontinae. Interestingly, Shi et al. [2005] even considered them as sister groups, although this paper was strongly criticized by Pitz et al. [2007]. In fact, the latter subfamily (as the tribe Charmontini) was previously included in the Homolobinae (see e.g. [Quicke \& van Achterberg, 1990]). However, subsequent phylogenetic studies regard Macrocentrinae and Charmontinae as more closely related [Sharanowski et al., 2011] or even sister groups [Belshaw \& Quicke, 2002; Dowton et al., 2002], whilst Homolobinae are considered as more distantly related to both of them. Nevertheless, since independent chromosomal fusions are believed to predominate in karyotype evolution of the family Braconidae [Gokhman, 2004] and parasitic Hymenoptera in general [Gokhman, 2009], karyotypic similarity of Charmontinae and Homolobinae can well be explained by parallel chromosomal fusions resulting in the specific structure of their karyotypes that contain a few pairs of relatively large biarmed chromosomes.
ACKNOWLEDGEMENTS. The authors are grateful to Sergey A. Belokobylskij (RAS Zoological Institute) for confirming the identification of $H$. infumator and providing useful taxonomic advice. This study is partly supported by a research grant no. 10-04-01521 from the Russian Foundation for Basic Research.

\section{References}

Belshaw R., Quicke D.L.J. 2002. Robustness of ancestral state estimates: evolution of life history strategy in ichneumonoid parasitoids // Systematic Biology. Vol.51. P.450-477.

Dowton M., Belshaw R., Austin A.D., Quicke D.L.J. 2002. Simultaneous molecular and morphological analysis of braconid relationships (Insecta: Hymenoptera: Braconidae) indicates independent mt-tRNA gene inversions within a single wasp family // Journal of Molecular Evolution. Vol.54. P.210-226.

Gokhman V.E. 2004. [Chromosomes of the family Braconidae (Hymenoptera)] // Trudy Russkogo Entomologicheskogo Obshchestva. Vol.75. No.1. P.96-101 [in Russian].

Gokhman V.E. 2009. Karyotypes of Parasitic Hymenoptera. Springer Science+Business Media B.V.: Dordrecht. XIII + 183 p.

Levan A., Fredga K., Sandberg A.A. 1964. Nomenclature for centromeric position on chromosomes // Hereditas. Vol.52. P.201220.

Pitz K.M., Dowling A.P.G., Sharanowski B.J., Boring C.A., Seltmann K.C., Sharkey M.J. 2007. Phylogenetic relationships among the Braconidae (Hymenoptera: Ichneumonoidea): A reassessment of Shi et al. (2005) // Molecular Phylogenetics and Evolution. Vol.43. P.338-343.

Quicke D.L.J., van Achterberg C. 1990. Phylogeny of the subfamilies of the family Braconidae (Hymenoptera: Ichneumonoidea) // Zoologische Verhandelingen. Vol.258. P.1-95.

Sharanowski B., Dowling A.P.G., Sharkey M.J. 2011. Molecular phylogenetics of Braconidae (Hymenoptera: Ichneumonoidea), based on multiple nuclear genes, and implications for classification // Systematic Entomology. Vol.36. P.549-572.

Shi M., Chen X.X., van Achterberg C. 2005. Phylogenetic relationships among the Braconidae (Hymenoptera: Ichneumonoidea) inferred from partial 16S rDNA, 28S rDNA D2, 18S rDNA gene sequences and morphological characters // Molecular Phylogenetics and Evolution. Vol.37. P.104-116. 